\title{
Extent of Utilization of Cloud Computing Resources by Students of Computer Science Education Department in Enugu State Universities, Nigeria
}

\author{
Eze Blessing Ngozi, Chiamogu Chiakonam Charles*, Mgboji Chukwuma, \\ Asogwa Nkechinyelugo Angela, Chilaka Akuchinyere Eunice
}

Department of Computer and Robotics Education, Faculty of Technical and Vocational Education, University of Nigeria, Nigeria

Received August 13, 2020; Revised October 1, 2020; Accepted October 19, 2020

\section{Cite This Paper in the following Citation Styles}

(a): [1] Eze Blessing Ngozi, Chiamogu Chiakonam Charles, Mgboji Chukwuma, Asogwa Nkechinyelugo Angela, Chilaka Akuchinyere Eunice, "Extent of Utilization of Cloud Computing Resources by Students of Computer Science Education Department in Enugu State Universities, Nigeria, "Universal Journal of Educational Research, Vol. 8, No. 11B, pp. 6072 - 6081, 2020. DOI: 10.13189/ujer.2020.082243.

(b): Eze Blessing Ngozi, Chiamogu Chiakonam Charles, Mgboji Chukwuma, Asogwa Nkechinyelugo Angela, Chilaka Akuchinyere Eunice (2020). Extent of Utilization of Cloud Computing Resources by Students of Computer Science Education Department in Enugu State Universities, Nigeria. Universal Journal of Educational Research, 8(11B), 6072 6081. DOI: 10.13189/ujer.2020.082243.

Copyright $\mathrm{C} 2020$ by authors, all rights reserved. Authors agree that this article remains permanently open access under the terms of the Creative Commons Attribution License 4.0 International License

\begin{abstract}
The study was carried out to find the assessment on cloud computing need of students of computer science education in Enugu state Universities. In carrying out the research, 4 research questions and 4 null hypotheses guided this research. Population for this research work is 1020 students. This consists of students of computer science education department in University of Nigeria Nsukka and (ESUT) Enugu state of Science and Technology. The entire population was studied. Data was collected with questionnaire and was analyzed with mean and $t$ test. After carrying out the analysis, it was revealed that cloud computing is utilized but not to a very large extent in storing of student data, also it was revealed that certain constraints hinder the utilization of online application of student registrations in Universities in Enugu state. It was recommended that a network-based management for cloud computing should be provided for universities in Enugu state to enable the improvement of students' academic performance in computer science education in Enugu state universities.
\end{abstract}

Keywords Cloud Computing, Cloud Computing Network Resources, Cloud Computing Servers, Cloud Computing Storage Resources, Cloud Computing Application Resources and Utilization

\section{Introduction}

The utilization of new technologies in universities to support teaching and learning has changed the way education is being carried out in the world. Educational sectors are able to share resources, collaborate, network, increase enrolment because of technologies. It is rampart to see many online certificates and degree programme being offered in many universities around the world. Educational sectors/institutions throughout the world have become highly dependent on technologies for conducting research, teaching and learning. They seek opportunity to rationalize the way they manage their resources. This opportunity has become even better with Cloud Computing (CC). $\mathrm{CC}$ is an attractive technology because of its dynamic scalabilities and effective use of the resources [1]. The author further explained that $\mathrm{CC}$ can be use under circumstance where the availabilities of resources are few. Cloud computing have been an important term in the world of Information Technology (IT), where computer education student is required to belong. Cloud computing resources are very important for all the students globally and computer 
education students will not be left behind. Cloud computing resources have made information/lecture note easy to access, store, share anywhere, anytime and at anyplace. $\mathrm{CC}$ is a type of computing which is very scalable and use virtualized resources that can be shared by the students of computer education.

\section{Cloud Computing}

Cloud computing is a kind of computing that rely on shared computing resource rather than having local server to handle application. CC to [2], is a type of Internet-based computing that provide shared computer processing resource and data for computer $\&$ other device on demand. Jyoti further explained that, $\mathrm{CC}$ is a model for enabling ubiquitous, on demand access to a shared pool of configurable computing resource, which can be rapidly released with little effort of management. In view of [3], $\mathrm{CC}$ and storage solution provides computer education student and enterprise with many capabilities to store and processes data privately. In the view of forgoing, [4] explained that cc is the delivery of on demand computing service, from application to storage and processing power over the internet. [1], [2], [3], stated that cc rely on sharing of resource to coherent scale, similar to utilities over an electricity network. Authors furthers explained that clouding computing is a process of enabling scalable and perfectly elastic software service with internet technology. In view of forgoing, Vangie [5] describes $\mathrm{CC}$ as a model for allowing ubiquitous network, server, storage, applications and service. CC to Love deep et al, has its benefits to include, Easy access to Lesson materials, no more carrying around devices, Stability, Security of data, shareability and trackability among others. Based on the above, there is a need for computer education student to properly make use of services and cloud computing networks

CC networks resources is a network that allows networks connectivity between cloud-based enabled application, services and solutions in which computer education student can share information among the students. Bala [6] explained that cloud computing networks resources serve as an infrastructural network capability and resource available host network. Furthermore, Vongie [7] describe that the use of cloud computing networks resources reduces students' number. Based on these computer education students for easy big data transfer will also require being able to access cloud computing servers' resources.

CC servers' resources are hosted, typically virtual, compute servers that are accessed by computer education students over a network. Cloud computing servers' resources can also be referred to as virtual servers, virtual private servers or virtual platforms [8]. According to [8], cloud servers' resources may also be a compute instance within an on-premises private cloud. The author further explains that in this case, an enterprise delivers the cloud server to internal users in which computer education student is part it across a local area network, and in some cases, also to external users across the internet. In the other hand, [7] enumerate the benefits of Cloud servers to include: stability, scalability, easy management and ease of access among others. Based on this, computer education students need to have access, stability and scalability of information and also be able to utilize cc storage resources.

$\mathrm{CC}$ storage resources are those devices or technology used in moving data offsite to a management service providers and protection of computer education student's information/Lecture materials. Cloud computing storage resources can complement on-premise storage and backup systems. Vongie [7] explained the benefits of cloud storage resources to include utility billing, global availability, ease of use, offsite security among others. The use of cloud computing storage resources will make the computer education students have easy access to backup information/lecture materials; in achieving this, there is a need for the student to make use of cloud computing application resources.

Cloud computing application resources are program-based in the internet where all the processing logic and data storage is done in the cloud. In view of [1],[2],[3], Cloud application resources tasks entails file storage, file sharing, email, order entries, inventories management and data collections among others. However, computer education students in other to carry out the listed tasks need to be able to utilize the cloud computing resources.

\section{Utilization}

Utilization is the primary technique wherein success and performance efficiency are determined for computer education students on the use of cloud computing resources. Educational institutions have started using ec in many ways, e.g. educator installs software in their computer, create a document and store it. Educator can access the documents within and outside the environment. $\mathrm{CC}$ provides IT resources and capabilities such as storage, communications, collaboration and applications. Cloud computing resources are very important for all the students globally and computer education students will not be left behind. Cloud computing resources have made information/lecture note easy to access, store, share anywhere, anytime and at anyplace. Based on this, there is a need to ascertain the utilization of cloud computing resources by the students of computer education at university in Enugu State. This is what this present study undertakes to find out.

\section{Statement of the Problems}

The education sector is faced with changes and reform, and it becomes necessary to reflect on issues concerned with emergence of cloud computing technologies \& 
accessibility of learning. Universities in Enugu state is not accessing the latest technology of productivity enhancement as demonstrated by low rates of cloud penetration. Universities in Enugu state in current times have witness level of insecurity. This made security threat to be a major problem for the universities in Enugu state and this brought massive allocations of the state budget for security. It is expected that teachers and organization adapted to a cloud technologies platform to deliver online learning. More online cloud-based applications should be used in Enugu State universities, UNN and ESUTH. Educators and students should adopt many of these cloud computing software services for their projects and assignments for it is easy-to-use and it uses learning-based approach that stand as one unique cloud-based platforms that encourage even technophobe and technologies virgin to access teaching and training module with smartphone and laptop. Institution can use limited faculties and content resource more efficiently by catering to more students worldwide.

\section{Purpose of the Study}

The purpose of the study is to find out extent of utilization of cloud Computing Resources by students of Computer Science Education in Enugu State universities; specifically, the study ought to determine the extent of;

1. utilization of cloud servers' resources by students of computer science education in Enugu State universities

2. utilization of cloud storage resources by students of computer science education in Enugu State universities

3. utilization of cloud application resources by student's computer science education in Enugu State universities

4. utilization of cloud computing resources by Enugu state universities

\section{Research questions}

1. What extent do computer science education students utilize cloud servers' resources?

2. To what extent do computer science education students utilize cloud storage resources?

3. To what extent do computer science education students utilize cloud application resources?

4. To what extent does Universities in Enugu state utilize cloud computing resources?

\section{Hypotheses}

$\mathbf{H o}_{1}$ : There is no significance difference between female and male student in the extent of utilization of cloud servers' resources by computer science Education Students in Universities in Enugu State.

Ho2: There is no significance difference between female and male student in the extent of utilization of cloud storage resources by computer science Education Students in Universities in Enugu State.

Ho3: There is no significance difference between female and male student in the extent of utilization of cloud application resources by computer science Education Students in Universities in Enugu State.

Ho4: There is no significance difference between UNN and ESUT in the extent of utilization of cloud computing resources by computer science Education student lecturers in Universities in Enugu State.

\section{Methodology}

\section{Research Design}

This study adopted the survey research design. The researcher considered survey design as the most appropriate design because this study solicited information's from the students of Universities within Enugu State on the extent of utilization of cloud computing resources by computer education students in university with questionnaire.

\section{Area of the Study}

The study was conducted in the two government-owned universities in UNN and ESUT in Enugu state. The choice in this area was based on the fact of its proximity as the Researcher had to make several trips for preliminary investigations in order to ascertain or authenticate facts and figures. The universities have almost the same characteristics and present the same problems. Their student makes use of cloud computing resources and there is a need to know the extent of the usage.

\section{Population}

The population of this study was 1020 respondents, which was made up of the computer education students in the study area.

\section{Sample}

Multistage sampling technique was used in this study. First: the two universities were selected with purposive sampling technique; ten per cent of the respondents of different categories were sampled for the study and was selected with proportionate sampling techniques. This is in line with Nwana in [13] who recommends that when the entire population is large, only a small portion of it is to constitute the sample, and if such population is a few thousands, five to ten per cent will do. Based on this, the ten per cent sample that will be drawn from the population of 1020 students is 102 comprised of student from ESUT and UNN.

\section{Instruments for Data Collection}

Questionnaire is the instruments and it was gotten from review of related literature. 


\section{Reliability of the Instrument}

The internal consistency of items is established by a single administration of the instrument to a similar group in Ebonyi State.

\section{Method of Data Collection}

Research assistants collected copies of completed questionnaire from the respondents after one week of distribution.

\section{Method of Data Analysis}

The collected data was analysed with mean, standard deviation and $t$ test statistics. Statistical Package for the Social Sciences was used for accuracy. Research question was analysed with mean and SD. 2.50 is the rating scale. T test was used to test the hypothesis, whose significance level is .05 . Result lower than .05 is rejected while higher than .05 is accepted.

\section{Results}

\section{Research Question 1}

To what extent do computer education student utilize cloud servers' resources?

Table 1. Mean response \& standard deviation extent does computer education students utilize cloud servers' resources

\begin{tabular}{|c|c|c|c|c|}
\hline $\mathbf{S} / \mathbf{N}$ & Items Statement & $\overline{\mathbf{X}}$ & $\begin{array}{c}\text { SD } \\
\mathbf{N}=\mathbf{1 0 2}\end{array}$ & Decision \\
\hline 1 & $\begin{array}{c}\text { I utilize cloud in } \\
\text { disaster recovery }\end{array}$ & 3.76 & 0.43 & HE \\
\hline 2 & $\begin{array}{c}\text { I utilize cloud to } \\
\text { reduce downtime in } \\
\text { cloud computing }\end{array}$ & 3.43 & 0.54 & HE \\
\hline 3 & $\begin{array}{c}\text { I utilize cloud in } \\
\text { scalability in case of } \\
\text { traffic data on the } \\
\text { website }\end{array}$ & 3.98 & 0.14 & HE \\
\hline 4 & $\begin{array}{c}\text { I utilize cloud to } \\
\text { switch to another } \\
\text { server in case of error }\end{array}$ & 3.87 & 0.34 & HE \\
\hline 5 & $\begin{array}{c}\text { I utilize cloud to } \\
\text { centralized } \\
\text { management system }\end{array}$ & 3.43 & 0.54 & HE \\
\hline
\end{tabular}

Note: $\overline{\mathbf{X}}$ : Mean, SD: Standard Deviation, N: No of the Respondent, $\mathbf{H E}=$ High Extent

Data in $1^{\text {st }}$ Table shows the mean response of the respondent on the 5 identified item relating to extent of utilization of cloud servers' resources by computer education students in Universities in Enugu State had mean ranging from $3.43-3.98$ which are higher than 2.50 scale. Standard deviation value for 5 items ranges from .14 to .54 ; it showed responses of the respondents are not far from its self and the mean. This shows that all the 5 items are the extent of utilization of cloud servers' resources by computer education students in Universities in Enugu State.

\section{Research Question Two}

To what extent do computer education students utilize cloud storage resources?

Table 2. Mean response and standard deviation extent does computer education students utilize cloud storage resources

\begin{tabular}{|c|c|c|c|c|}
\hline $\mathrm{S} / \mathrm{N}$ & Items Statement & $\overline{\mathbf{X}}$ & $\begin{array}{c}\mathrm{SD} \\
\mathrm{N}=102\end{array}$ & Decision \\
\hline 1 & $\begin{array}{l}\text { I use cloud in Scalable } \\
\text { storage }\end{array}$ & 3.98 & 0.14 & $\mathrm{HE}$ \\
\hline 2 & $\begin{array}{l}\text { I utilize cloud in disaster } \\
\text { recovery }\end{array}$ & 3.87 & 0.34 & $\mathrm{HE}$ \\
\hline 3 & $\begin{array}{l}\text { I utilize cloud to } \\
\text { document editing }\end{array}$ & 3.98 & 0.14 & $\mathrm{HE}$ \\
\hline 4 & $\begin{array}{c}\text { I utilize cloud in } \\
\text { e-signatures }\end{array}$ & 3.87 & 0.34 & $\mathrm{HE}$ \\
\hline 5 & $\begin{array}{l}\text { I utilize cloud in mobile } \\
\text { phone access or native } \\
\text { application }\end{array}$ & 3.74 & 0.44 & $\mathrm{HE}$ \\
\hline 6 & $\begin{array}{l}\text { I utilize cloud in Portal } \\
\text { white-labeling }\end{array}$ & 3.54 & 0.50 & $\mathrm{HE}$ \\
\hline 7 & $\begin{array}{l}\text { I utilize cloud in server } \\
\text { backup }\end{array}$ & 3.76 & 0.43 & $\mathrm{HE}$ \\
\hline 8 & $\begin{array}{l}\text { I utilize cloud in idle } \\
\text { backup }\end{array}$ & 3.43 & 0.54 & $\mathrm{HE}$ \\
\hline 9 & $\begin{array}{l}\text { I utilize cloud in external } \\
\text { drive backup }\end{array}$ & 3.98 & 0.14 & $\mathrm{HE}$ \\
\hline 10 & $\begin{array}{l}\text { I utilize cloud in mobile } \\
\text { passcode }\end{array}$ & 3.87 & 0.34 & $\mathrm{HE}$ \\
\hline 11 & $\begin{array}{l}\text { I utilize cloud in device } \\
\text { and location tracking }\end{array}$ & 3.43 & 0.54 & $\mathrm{HE}$ \\
\hline 12 & $\begin{array}{c}\text { I utilize cloud in } \\
\text { Multi-factor } \\
\text { authentication/verification } \\
\text { process }\end{array}$ & 3.98 & 0.14 & $\mathrm{HE}$ \\
\hline
\end{tabular}

Note: $\overline{\mathbf{X}}$ : Mean, SD: Standard Deviation, N: No of the Respondent, $\mathbf{H E}=$ High Extent

Data in $2^{\text {nd }}$ table shows the mean response of respondent on 12 identified items relating to extent of utilization of cloud storage resources by computer education students in Universities in Enugu State had mean ranging from 3.43 3.98 which is higher than 2.50 on a 4 scale. Standard deviation for 12 items ranged from .14 - .54 which showed the respondent is not far from their responses and the mean. This shows that all the 12 items are the extent of utilization of cloud storage resources by computer education students in Universities in Enugu State.

\section{Research Question Three}

To what extent do computer education students utilize cloud application resources? 
Table 3. Mean response and standard deviation extent does computer education students utilize cloud application resources

\begin{tabular}{|c|c|c|c|c|}
\hline S/N & Items Statement & $\overline{\mathbf{X}}$ & $\begin{array}{c}\text { SD } \\
\text { N=102 }\end{array}$ & Decision \\
\hline 1 & I utilize cloud to submit seminar papers through online & 3.87 & 0.34 & HE \\
\hline 2 & I utilize cloud to access works taken in related area and in the global contest & 3.43 & 0.54 & HE \\
\hline 3 & I utilize cloud to get data with web-tools for article preparation & 3.98 & 0.14 & HE \\
\hline 4 & I utilize cloud to access web resources anytime for enhancing my computer skill & 3.87 & 0.34 & HE \\
\hline 5 & I use cloud to visit educational website for new updates & 3.98 & 0.14 & HE \\
\hline 6 & I use cloud for web-based materials for my study & 3.87 & 0.34 & HE \\
\hline 7 & I use cloud to download statistical package for data analysis & 3.74 & 0.44 & HE \\
\hline 8 & I use cloud to get free application with web-tools & 3.54 & 0.50 & HE \\
\hline 9 & I use cloud to Google applications for my research related works & 3.76 & 0.43 & HE \\
\hline 10 & I use cloud to study articles online before choosing topics for seminar & 3.43 & 0.54 & HE \\
\hline 11 & I use cloud to include YouTube videos in my paper presentations & 3.98 & 0.14 & HE \\
\hline 12 & I use cloud to post my prepared presentations in internet & 3.87 & 0.34 & HE \\
\hline 13 & I use cloud to enjoy Storage area provided by web tools & 3.43 & 0.54 & HE \\
\hline 14 & I utilize cloud in online money transaction for my study purposes & 3.98 & 0.14 & HE \\
\hline
\end{tabular}

Note: $\overline{\mathbf{X}}$ : Mean, SD: Standard Deviation, N: No of the Respondent, HE= High Extent

Table 4. T test analysis on extent of utilization of cloud network resources by computer Education Students in Universities in Enugu State

\begin{tabular}{|c|c|c|c|c|c|c|c|c|}
\hline $\mathrm{S} / \mathrm{N}$ & Items Statement & GROUPS & $\mathrm{X}$ & S. D & $\mathrm{DF}$ & T-cal & P-VALUE & REMARK \\
\hline \multirow{2}{*}{1} & \multirow{2}{*}{ I utilize cloud in in-house network. } & Male & 3.38 & 0.55 & 100 & 0.12 & 0.21 & NS \\
\hline & & Female & 3.51 & 0.51 & & & & \\
\hline \multirow{2}{*}{2} & \multirow{2}{*}{ I utilize cloud to share data/information. } & Male & 4.00 & 0.00 & 100 & 13.63 & 0.08 & NS \\
\hline & & Female & 3.95 & 0.22 & & & & \\
\hline \multirow{2}{*}{3} & \multirow{2}{*}{$\begin{array}{l}\text { Use I utilize cloud network to share single internet } \\
\text { connection. }\end{array}$} & Male & 3.95 & 0.22 & 100 & 43.19 & 0.10 & NS \\
\hline & & Female & 3.76 & 0.43 & & & & \\
\hline \multirow{2}{*}{4} & \multirow{2}{*}{ I utilize cloud to control over sharing permissions } & Male & 3.87 & 0.34 & 100 & 46.39 & 0.20 & NS \\
\hline & & Female & 3.54 & 0.50 & & & & \\
\hline \multirow{2}{*}{5} & \multirow{2}{*}{ I utilize cloud in password-protected sharing } & Male & 3.59 & 0.50 & 100 & 0.85 & 0.21 & NS \\
\hline & & Female & 3.46 & 0.50 & & & & \\
\hline
\end{tabular}

Note: X: Mean, SD: Standard Deviation, DF= Degree of Freedom, $\mathbf{S}=$ Significance, NS: Not Significance

$3^{\text {rd }}$ table shows the mean response of the respondents on 14 identified items relating to extent of utilization of cloud application resources by computer education students in Universities in Enugu State had mean ranging from 3.43 3.98 which is higher than 2.50. Standard deviation value for 14 items from .14 to .54 , which showed the respondents are not far in their response and the responses not far from the mean. This shows that all the 14 items are the extent of utilization of cloud application resources by computer education students in Universities in Enugu State.

\section{Hypotheses}

$\mathbf{H o}_{1}$ : There is no significance different between female and male students in extent of utilization of cloud network resources by computer Education Students in Enugu State universities. $4^{\text {th }}$ table shows the t-test scores of male and female computer Education students on extent of utilization of cloud network resources by computer Education Student's in Enugu State universities. The analysis shows that the 5 identified items on utilization of cloud network resource by computer Education Students in Universities in Enugu State had p-value from .08 to .21 which is higher than .05 . It indicates the no significance difference in responses of female and male students on extent utilization of cloud network resources by computer Education Students in Universities in Enugu State.

$\mathrm{Ho}_{2}$ : There is no significance different between female and male students in extent of utilization of cloud storage resources by computer Education Students in Enugu State Universities. 
Table 5. T test analysis on extent of utilization of cloud storage resources by computer Education Students in Universities in Enugu State

\begin{tabular}{|c|c|c|c|c|c|c|c|c|}
\hline $\mathbf{S} / \mathbf{N}$ & Items Statement & GROUPS & $\mathbf{X}$ & S. D & DF & T-cal & P-VALUE & REMARK \\
\hline \multirow{2}{*}{1} & \multirow{2}{*}{ I use cloud in Scalable storage } & Male & 4.00 & 0.00 & 100 & 13.63 & 0.08 & NS \\
\hline & & Female & 3.95 & 0.22 & & & & \\
\hline \multirow{2}{*}{2} & \multirow{2}{*}{ I utilize cloud in disaster recovery } & Male & 3.95 & 0.22 & 100 & 43.19 & 0.05 & NS \\
\hline & & Female & 3.76 & 0.43 & & & & \\
\hline \multirow{2}{*}{3} & \multirow{2}{*}{ I utilize cloud to document editing } & Male & 4.00 & 0.00 & 100 & 13.63 & 0.08 & NS \\
\hline & & Female & 3.95 & 0.22 & & & & \\
\hline \multirow{2}{*}{4} & \multirow{2}{*}{ I utilize cloud in e-signatures } & Male & 3.95 & 0.22 & 100 & 43.19 & 0.10 & NS \\
\hline & & Female & 3.76 & 0.43 & & & & \\
\hline \multirow{2}{*}{5} & \multirow{2}{*}{$\begin{array}{l}\text { I utilize cloud in mobile phone access or native } \\
\text { application }\end{array}$} & Male & 3.87 & 0.34 & 100 & 46.39 & 0.20 & NS \\
\hline & & Female & 3.54 & 0.50 & & & & \\
\hline \multirow{2}{*}{6} & \multirow{2}{*}{ I utilize cloud in Portal white-labeling } & Male & 3.59 & 0.50 & 100 & 0.85 & 0.21 & NS \\
\hline & & Female & 3.46 & 0.50 & & & & \\
\hline \multirow{2}{*}{7} & \multirow{2}{*}{ I utilize cloud in server backup } & Male & 3.89 & 0.32 & 100 & 49.22 & 0.07 & NS \\
\hline & & Female & 3.59 & 0.50 & & & & \\
\hline \multirow{2}{*}{8} & \multirow{2}{*}{ I utilize cloud in idle backup } & Male & 3.38 & 0.55 & 100 & 0.12 & 0.21 & NS \\
\hline & & Female & 3.51 & 0.51 & & & & \\
\hline \multirow{2}{*}{9} & \multirow{2}{*}{ I utilize cloud in external drive backup } & Male & 4.00 & 0.00 & 100 & 13.63 & 0.08 & NS \\
\hline & & Female & 3.95 & 0.22 & & & & \\
\hline \multirow{2}{*}{10} & \multirow{2}{*}{ I utilize cloud in mobile passcode } & Male & 3.95 & 0.22 & 100 & 43.19 & 0.06 & NS \\
\hline & & Female & 3.76 & 0.43 & & & & \\
\hline \multirow{2}{*}{11} & \multirow{2}{*}{ I utilize cloud in device and location tracking } & Male & 3.38 & 0.55 & 100 & 0.12 & 0.21 & NS \\
\hline & & Female & 3.51 & 0.51 & & & & \\
\hline \multirow{2}{*}{12} & \multirow{2}{*}{$\begin{array}{l}\text { I utilize cloud in Multi-factor authentication/verification } \\
\text { process }\end{array}$} & Male & 4.00 & 0.00 & 100 & 13.63 & 0.08 & NS \\
\hline & & Female & 3.95 & 0.22 & & & & \\
\hline
\end{tabular}

Note: X: Mean, SD: Standard Deviation, DF= Degree of Freedom, $\mathbf{S}=$ Significance, NS: Not Significance

$5^{\text {th }}$ table shows $t$ test scores of male $\&$ female students on extent of utilization of cloud storage resources by computer Education Students in Enugu State universities. The analysis shows that 12 identified items on utilization of cloud storage resource by computer Education Students in Universities in Enugu State had p-values from .05 to .10 which are higher than 0.05 . It indicates the no significance difference between responses of male and female students on utilization of cloud storage resources by computer Education Students in Enugu State universities.

$\mathrm{Ho}_{3}$ : There is no significance different between male \& female student on utilization of cloud application resources by computer Education Students in Enugu State universities. 
Table 6. T test analysis on extent of utilization of cloud application resources by computer Education Students in Universities in Enugu State

\begin{tabular}{|c|c|c|c|c|c|c|c|c|}
\hline $\mathbf{S} / \mathbf{N}$ & Items Statement & GROUPS & $\mathbf{X}$ & S. D & DF & T-cal & P-VALUE & REMARK \\
\hline \multirow{2}{*}{1} & \multirow{2}{*}{ I utilize cloud to submit seminar papers through online } & Male & 3.95 & 0.22 & 100 & 43.19 & 0.08 & NS \\
\hline & & Female & 3.76 & 0.43 & & & & \\
\hline \multirow{2}{*}{2} & \multirow{2}{*}{$\begin{array}{l}\text { I utilize cloud to access works taken in related areas and } \\
\text { in global contest }\end{array}$} & Male & 3.38 & 0.55 & 100 & 0.12 & 0.00 & $\mathrm{~S}$ \\
\hline & & Female & 3.51 & 0.51 & & & & \\
\hline \multirow{2}{*}{3} & \multirow{2}{*}{$\begin{array}{l}\text { I utilize cloud to access data with web-tools for article } \\
\text { preparation }\end{array}$} & Male & 4.00 & 0.00 & 100 & 13.63 & 0.08 & NS \\
\hline & & Female & 3.95 & 0.22 & & & & \\
\hline \multirow{2}{*}{4} & \multirow{2}{*}{$\begin{array}{l}\text { I utilize cloud to access web resources anytime for } \\
\text { enhancing my computer skill }\end{array}$} & Male & 3.95 & 0.22 & 100 & 43.19 & 0.00 & $\mathrm{~S}$ \\
\hline & & Female & 3.76 & 0.43 & & & & \\
\hline \multirow{2}{*}{5} & \multirow{2}{*}{ I use cloud to visit educational website for new updates } & Male & 4.00 & 0.00 & 100 & 13.63 & 0.00 & $\mathrm{~S}$ \\
\hline & & Female & 3.95 & 0.22 & & & & \\
\hline \multirow{2}{*}{6} & \multirow{2}{*}{ I use cloud for web-based materials for my study } & Male & 3.95 & 0.22 & 100 & 43.19 & 0.21 & NS \\
\hline & & Female & 3.76 & 0.43 & & & & \\
\hline \multirow{2}{*}{7} & \multirow{2}{*}{$\begin{array}{l}\text { I use cloud to download statistical package for data } \\
\text { analysis }\end{array}$} & Male & 3.87 & 0.34 & 100 & 46.39 & 0.10 & NS \\
\hline & & Female & 3.54 & 0.50 & & & & \\
\hline \multirow{2}{*}{8} & \multirow{2}{*}{ I use cloud to get free applications with web-tools } & Male & 3.59 & 0.50 & 100 & 0.85 & 0.21 & NS \\
\hline & & Female & 3.46 & 0.50 & & & & \\
\hline \multirow{2}{*}{9} & \multirow{2}{*}{$\begin{array}{l}\text { I use cloud to Google applications for my research } \\
\text { related works }\end{array}$} & Male & 3.89 & 0.32 & 100 & 49.22 & 0.08 & NS \\
\hline & & Female & 3.59 & 0.50 & & & & \\
\hline \multirow{2}{*}{10} & \multirow{2}{*}{$\begin{array}{l}\text { I use cloud to read articles online before choosing topic } \\
\text { for seminar presentation }\end{array}$} & Male & 3.38 & 0.55 & 100 & 0.12 & 0.08 & NS \\
\hline & & Female & 3.51 & 0.51 & & & & \\
\hline \multirow{2}{*}{11} & \multirow{2}{*}{$\begin{array}{l}\text { I use cloud to include YouTube videos in my paper } \\
\text { presentations }\end{array}$} & Male & 4.00 & 0.00 & 100 & 13.63 & 0.21 & NS \\
\hline & & Female & 3.95 & 0.22 & & & & \\
\hline \multirow{2}{*}{12} & \multirow{2}{*}{ I use cloud to post my prepared presentations in internet } & Male & 3.95 & 0.22 & 100 & 43.19 & 0.08 & NS \\
\hline & & Female & 3.76 & 0.43 & & & & \\
\hline \multirow{2}{*}{13} & \multirow{2}{*}{ I use cloud to enjoy Storage area provided by web tools } & Male & 3.38 & 0.55 & 100 & 0.12 & 0.10 & NS \\
\hline & & Female & 3.51 & 0.51 & & & & \\
\hline \multirow{2}{*}{14} & \multirow{2}{*}{$\begin{array}{c}\text { I utilize cloud in online money transaction for my study } \\
\text { purposes }\end{array}$} & Male & 4.00 & 0.00 & 100 & 13.63 & 0.21 & NS \\
\hline & & Female & 3.95 & 0.22 & & & & \\
\hline
\end{tabular}

Note: X: Mean, SD: Standard Deviation, DF= Degree of Freedom, S= Significance, NS: Not Significance

$6^{\text {th }}$ table shows the t-test scores of male and female computer students on utilization of cloud application resources by computer Education Students in Enugu State universities. The analysis shows that the 14 identified items on utilization of cloud application resource by computer Education Students in Universities in Enugu State had p-values from .00 to .21 which are all higher than .05 . Thus, it indicates the no significance difference in responses of male and female students on utilization of cloud storage resources by computer Education Students in Enugu State universities.

P-value of remaining items of male and female computer students on utilization of cloud application resources by computer Education Students in Universities in Enugu State, specifically items 24,26 and 27 are less than the .05 significance level. Thus, there is significance difference on responses of male and female computer students in the extent of utilization of cloud application resources by computer Education Students in Universities in Enugu State.

\section{Research question}

4. To what extent does Universities in Enugu state utilize cloud computing resources?

$\mathrm{Ho}_{4}$ : There is no significant different between UNN and ESUT in the extent of utilization of cloud computing resources by computer Education student/lecturers in Enugu State universities. 
Table 7. T test analysis on extent of utilization of cloud computing resources by Universities in Enugu State

\begin{tabular}{|c|c|c|c|c|c|c|c|c|}
\hline $\mathbf{S} / \mathbf{N}$ & Items Statement & GROUPS & $\mathbf{X}$ & S. D & DF & T-cal & P-VALUE & REMARK \\
\hline \multirow{2}{*}{1} & \multirow{2}{*}{ I use cloud in Scalable storage } & UNN & 4.00 & 0.08 & 100 & 12.63 & 0.09 & NS \\
\hline & & ESUT & 3.95 & 0.32 & & & & \\
\hline \multirow{2}{*}{2} & \multirow{2}{*}{ I utilize cloud in disaster recovery } & UNN & 3.95 & 0.32 & 100 & 42.19 & 0.07 & NS \\
\hline & & ESUT & 3.76 & 0.43 & & & & \\
\hline \multirow{2}{*}{3} & \multirow{2}{*}{ I utilize cloud to document editing } & UNN & 4.00 & 0.05 & 100 & 23.63 & 0.07 & NS \\
\hline & & ESUT & 3.95 & 0.22 & & & & \\
\hline \multirow{2}{*}{4} & \multirow{2}{*}{ I utilize cloud to submit seminar papers through online } & UNN & 3.95 & 0.22 & 100 & 33.19 & 0.10 & NS \\
\hline & & ESUT & 3.76 & 0.43 & & & & \\
\hline \multirow{2}{*}{5} & \multirow{2}{*}{$\begin{array}{l}\text { I utilize cloud to access works taken in the related areas } \\
\text { and in the global contest }\end{array}$} & UNN & 3.87 & 0.34 & 100 & 46.39 & 0.30 & NS \\
\hline & & ESUT & 3.54 & 0.50 & & & & \\
\hline \multirow{2}{*}{6} & \multirow{2}{*}{$\begin{array}{l}\text { I utilize cloud to access data through web-tools for } \\
\text { article preparation }\end{array}$} & UNN & 3.59 & 0.50 & 100 & 0.85 & 0.31 & NS \\
\hline & & ESUT & 3.46 & 0.50 & & & & \\
\hline \multirow{2}{*}{7} & \multirow{2}{*}{$\begin{array}{c}\text { I utilize cloud in disaster recovery } \\
\text { I utilize cloud to reduce downtime in cloud computing }\end{array}$} & UNN & 3.89 & 0.32 & 100 & 49.22 & 0.07 & NS \\
\hline & & ESUT & 3.59 & 0.50 & & & & \\
\hline \multirow{2}{*}{8} & \multirow{2}{*}{$\begin{array}{l}\text { I utilize cloud in scalability in case of traffic data on the } \\
\text { website }\end{array}$} & UNN & 3.38 & 0.55 & 100 & 0.12 & 0.21 & NS \\
\hline & & ESUT & 3.51 & 0.51 & & & & \\
\hline \multirow{2}{*}{9} & \multirow{2}{*}{ I utilize cloud in disaster recovery } & UNN & 4.00 & 0.00 & 100 & 13.63 & 0.08 & NS \\
\hline & & ESUT & 3.95 & 0.22 & & & & \\
\hline \multirow{2}{*}{10} & \multirow{2}{*}{ I utilize cloud to reduce downtime in cloud computing } & UNN & 3.95 & 0.22 & 100 & 43.19 & 0.06 & NS \\
\hline & & ESUT & 3.76 & 0.43 & & & & \\
\hline
\end{tabular}

Note: X: Mean, SD: Standard Deviation, DF= Degree of Freedom, $\mathbf{S}=$ Significance, NS: Not Significance

Table 7 shows the t-test scores of UNN and ESUT students on utilization of cloud computing resource by computer Education Student in University in Enugu State. Analysis shows that 10 identified items on utilization of cloud computing resources by computer Education Students in Universities in Enugu State had p-values from .06 to .30 which are all higher than .05 . These indicate no significance difference in the responses of UNN and ESUT students on utilization of cloud computing resources by computer Education Students in Universities in Enugu State.

\section{Discussion}

Findings of this study are arranged and discussed based on the research questions answered and the hypotheses tested.

\section{A. Extent of utilization of cloud servers' resources by computer education students in Universities in Enugu State}

The data in table 1 supplied the answer to research question 1 . The finding revealed the mean score for the extent of utilization of cloud server resources by computer education students in Universities in Enugu State is higher than 2.50 , which means that it's very high that computer education students make use of cloud servers' resources in Universities in Enugu State. T- test analysis was used to test the 1 st hypothesis; $4^{\text {th }}$ table shows that P-value are higher than the confidence level of .05 thus indicating the no significant difference between male and female student in the extent of utilization of cloud server resources by computer Education Students in Universities in Enugu State. The finding is similar to the view of [7], which states that cloud servers' resources may also be a compute instance within an on-premises private cloud. The author further explains that in this case, universities delivers the cloud server to internal users in which computer education student is part it across a local area network, and in some cases, also to external users across the internet. In the other hand, [5], enumerate the benefits of Cloud servers to computer education students which include stability, scalability, easy management and ease of access among others

\section{B. Extent of utilization of cloud storage resources by computer education students in Universities in Enugu State}

The data in table 2 supplied answers to research question 2. The finding revealed the mean score for the extent of utilization of cloud storage resources by computer education students in Universities in Enugu State is higher than 2.50 , which means that it's very high that computer 
education students make use of cloud storage resources in Universities in Enugu State. T- test analysis was used to test the first hypothesis; the $5^{\text {th }}$ table shows that P-value is higher than the confidence level of .05 thus indicating that there is no significance difference between male and female student in the extent of utilization of cloud storage resources by computer Education Students at Universities in Enugu State. The finding is similar to the view of [7], which explained the benefits of cloud storage resources to computer education students which included utility billing, global availability, ease of use, offsite security among others. The use of cloud computing storage resources will make the computer education students have easy access to backup information/lecture materials; in achieving this, there is a need for the student to make use of cloud computing application resources.

\section{Extent of utilization of cloud application resources by computer education students in Universities in Enugu State}

Data presented in table 3 gave answers to research question 3. The finding reveals the mean score for the extent of utilization of cloud application resources by computer education students at Universities in Enugu State is higher than 2.50, which means that it's very high that computer education students make use of cloud application resources at Universities in Enugu State. T- test analysis was-used to-test the hypotheses in table 6.6 shows that $\mathrm{P}$-value are more than confidence level .05 thus indicating that there was no significant difference between male and female student in the extent of utilization of cloud application resources by computer Education Students at Universities in Enugu State. The finding is similar to the view of [14] which said that Cloud computing applications provide long term mailing service and web-based application which are accessible with a variety of computer and mobile platform. Students can freely share their data in the cloud computing applications. Usefulness of Cloud Computing Application in Education, by availing the service and cloud computing the following benefit can enjoy in the domain of education. Students can submit their seminar paper through online. Student can check the research work undertaken in the areas related to their research's area in the global contest. Students can collect data through web tool for preparing articles. Students can access at any time the web resource for enhancing their computer skills. Student can visit the educational websites for new update. Students can use web-based material for their study. Student can download statistical packages for data analysis. Students can download free software with the help of web tool. Students can use Google application for their research related work. Students can read many research articles through online before selecting topics for their seminar presentations. Students can make use of YouTube videos in their paper presentations. Students can post their prepared presentations in internet. Students can enjoy storage area provided by web tools. Students can use online money transaction for their study purposes, and these apart they can enjoy a lot of benefit's exploiting cloud computing facility. Zach [10] described that from the user perspectives, the cloud application behave like a standard website, but the computing and data processing are handles by the cloud via an API (application program interface) or hybrid of both. In view of [1],[2],[3] Cloud application resources tasks encompasses e-mail, file-storages and sharings, order entries, inventories management, words processing, customers relationships management, data collections among others

\section{Conclusions}

Cloud computing is new in education sector. How to use cloud computing in university are taught to Enugu State staff in charge of students' results and students equally for the improvement of their academic performance. Cloud computing resources are very important for all the students globally and computer education students will not be left behind. Cloud computing resources have made information/lecture note easy to access, store, share anywhere, anytime and at anyplace. This enable them carry out their work properly in cloud computing. Lecturers should be allowed to have access to management information system (MIS) website to enable them verify the authenticity and accuracy of students' or transcript before issuance. This will avoid manipulation and forgery of results in universities in Enugu state.

\section{Acknowledgements}

The researchers are thankful to Benardine Ifeoma Ona $(\mathrm{PhD})$ for her assistance and also want to thank all the co-authors from Computer and Robotic Education, Vocational and Technical Education faculty, University of Nigeria, Nsukka.

\section{REFERENCES}

[1] Lovedeep, U (2017). Concept, principle and method for management of electronics records. The information's societies, 11(3) 251-269.

[2] Jyoti, V. (2017). Student records 'just a red tape'. TLS Education ltd.

[3] Harpreet, B (2017). Intelligent ITs infrastructures for the futures. 14th International Symposiums on High performances Compute Architectures, Proceeding, March 17-19.

[4] Steve, E (2018). Element of information management'. New Jersey; scare crow press. 
[5] Vongi, G (2019). Automatic identification data capture (AIDC) 100`AIDC 100: professionals who excel in saving the AIDC industry. Archived from the original on July 2019. Retrieved August 13, 2019.

[6] Bala, E (2014). Introduction to computer systems Evolution, Architecture, Assembly language programming. Academic publishing company Enugu.

[7] Vongie, W (2019). How to manage your records. Paris: ICSA publication Technology standards for teachers.

[8] Margaret, E (2018). Effective Uses of Clouds Compute in Educational Institution," Procedia Socials and Behavioural Science, 5 (6), 948-952.

[9] Rich, B (2018). Introduction to computer science. Beginners Hand Book of Practical Computer Knowledge. Fourth Dimension Publications, 2018.

[10] Zach, H (2018). Generations Computers System-the International Journals of Grids Compute Theories Method and Application, 27, (7), 170-182.

[11] Ajith, N. \& Hemalatha, L. (2012). Computing and storages cloud using wide areas high performances network. Futures.

[12] Onah, B. I, Ugwuoke, C. U, Chigbu, B. C. (2018). Values additions in Careers and Technical Educetion through Entrepreneurships Educations: Enhancing the Humans Capitasl Potential of Nigeria Students. CTE Research Journal, Pg 118-126.

[13] Onah, B.I, Jimoh Bakare, Eze, B. N. Uzoegwu. C.R. (2018). Assessments of Computers Robotic Programming Need of Computers Educations and Electricals/Electronics Technologies Students for improving academics Performances in the University in Southern Nigeria. International Journal of Applied Engineering Research ISSN 0973-4562 13(24), 1119-1127. SCImago.

[14] Aymarich, E. U, Fena, O., Surcies, X. (2018). Approach to Cloud Computing. International Conference in application of digital informations and webs technology, Ostravia, XZECH REPUBLICA, 127-130. 